\title{
Optimization of FDM Printing Parameters for Surface Quality Improvement of Carbon Based Nylon (PA-CF) Composite Material Fabricated Parts Using Evolutionary Algorithm
}

\author{
Sandeep ${ }^{1}$, Deepak Chhabra ${ }^{1, *}$, R.K. Gupta ${ }^{2}$ \\ ${ }^{1}$ Department of Mechanical Engineering, UIET, Maharshi Dayanand University, Rohtak Haryana, India \\ ${ }^{2}$ Department of Mechanical Engineering, Manipal University Jaipur, Jaipur, Rajasthan, India
}

(Received 12 January 2021; revised manuscript received 25 March 2021; published online 09 April 2021)

\begin{abstract}
The surface characteristics of components fabricated by additive manufacturing techniques are greatly affected by the input parameters. In this work, momentous input factors (layer thickness $(L T)$, temperature $(T)$, printing speed (S), outer wall speed (OWS), raster angle $(R A)$, orientation (Or.), outer wall line width $(O W L W)$, infill overlap (IO), infill line width (ILW) of fused deposition modeling (FDM) printer are modeled and optimized for getting the better surface roughness $(S R)$ of carbon based nylon (PA-CF) composite material fabricated parts. To develop input experimental matrix, central composite design method has been utilized and on these input parameters, surface roughness of each run has been measured using Mitutoyo Talysurf surface roughness measuring instrument. A total number of 61 specimens have been fabricated on different input parameters and their surface roughnesses are tested. The minimum surface roughness value of test specimens with experimental design matrix was recorded as $6.331 \mu \mathrm{m}$. The modeling and optimization of experimental design matrix has been carried out using evolutionary algorithm i.e. artificial neural network integrated with genetic algorithm (ANNGA). The minimum value obtained using ANNGA for roughness is $5.01788 \mu \mathrm{m}$, corresponding to various optimum input factors as $L T=0.1776 \mathrm{~mm}, T=236.0609^{\circ} \mathrm{C}, \quad S=40.7369 \mathrm{~mm} / \mathrm{s}$, $O W S=20.0676 \mathrm{~mm} / \mathrm{s}, R A=43.9177^{\circ}, O W L W=0.3445 \mathrm{~mm}, O r .=0.0018^{\circ}, I O=56.6295 \%, I L W=0.3488 \mathrm{~mm}$. At these optimized input factors value one end-use part is also fabricated and the developed hybrid model is validated. The artificial neural network integrated with genetic algorithm could be anticipated for better prophecy, factors optimization and outcomes for any engineering application tribulations.
\end{abstract}

Keywords: Fused deposition modeling, Artificial neural network integrated with genetic algorithm, Surface roughness, Experimental design matrix, Optimization.

DOI: $10.21272 /$ jnep.13(2).02004

PACS numbers: 68.35.Ct, 62.23.Pq

\section{INTRODUCTION}

The different product development fight in the global market is rising enormously and for manufacturing units to sustain in the market it is important that, how at the outset they are providing the required product in the market. FDM is one such additive manufacturing technique which can fabricates parts directly from any design software data file or any scanned data file. FDM introduced by Stratasys Inc. (1990) and based on extrusion principle, fabricate parts by depositing thermoplastic as a base material in additive way straightly from a designed data model file $[1,2]$. FDM is finding wide range of application areas in the field of aerospace industry, automobile, medical inserts, civil engineering and many more without need of any high cost tooling and instruments [3-5]. Along with fabrication of prototype of any functional model, FDM is also using to fabricate end use application products [6]. However, at the mass production level the use of FDM is still at limited level due to the lack of preciseness value of fabricated parts, surface roughness $(S R)$ and bad mechanical performance [7]. Therefore, to be strong competitor among various manufacturing units and have a large global market shares, it is indispensable to fabricate products firstly and perfectly. For FDM fabricated parts, $S R$ is the one of most important characteristic that can play important role in its development and could provide final fabricated parts with all required finishing stipulations. However, it is difficult to meet the required speci- fy specifications due to limited availability of material in the filament form and numbers of conflicting process parameters that FDM machines have. Subsequently, the working conditions that ideally suit a material and optimum parameters combination must be utilized and their attributes must be considered.

Many researchers have considered the impact of an assortment of input parameters on FDM manufactured components quality and furthermore a lot more have made effort to improve the output response value by optimizing the parameters [8-10]. Wang et al. [11] examined the effect of input parameters on dimensional preciseness and surface roughness of FDM manufactured parts. Layer thickness among the examined factors; found most significant factor that affect the surface roughness significantly. Vasudevarao et al. [12] studied the impact of part orientation, layer height, raster width, temperature, and air gap on the surface quality of parts manufactured. The design of different sets of parameters is developed using factorial design (half) technique. The outcomes of the experimental runs showed that the better surface quality is achieved at low value of layer thickness and $0^{\circ}$ build orientation. As per Anitha et al. [13] layer thickness is the most important parameter other than speed and raster width that affect the quality of surface significantly. Additionally Thrimurthulu et al. [14] suggested a low value of layer height for good surface finishing. Horvath et al. [15] exercised the full factorial design to know the effect of

*deepak.chhabra@mdurohtak.ac.in

The results were presented at the International Conference on Multifunctional Nanomaterials (ICMN2020) 
FDM input factors on surface quality. Liu et al. [16] used Taguchi method for examining the impact of parameters (layer thickness, raster width, raster orientation, build orientation and raster gap) on mechanical characteristics of FDM parts. Sood et al. [17] used desirability function approach for optimization of mechanical characteristics of FDM printed parts, in place of gray Taguchi technique and found more precise results than Taguchi method. Also Akande [18] used desirability function approach for multi-objective optimization problem and found optimum parameters combination set for the desired responses value. Peng et al. [19] exercised response surface methodology (RSM), fuzzy logic, combined with genetic algorithm (GA) to get optimum results for considered outcomes (three in numbers). Nancharaiah et al. [20] considered Taguchi and analysis of variance (ANOVA) method for modeling and analyzing the nature of different FDM input factors on surface quality of ABS material parts. Mohamed et al. [6] have looked on different optimization procedures like Response surface methodology, Taguchi, factorial design, gray relational, artificial neural network, fuzzy logic, and combined with GA for modeling and to optimize FDM input factors. Assarzadeh and Ghoreshi [21], Agarwal et al. [22] applied ANN technique for optimizing the input factors. In correlation with arithmetical based model they found an inexorably precise evaluation with ANN-based model.

From the above research works, it is clear that a large part of studied literature are mainly centered on optimizing the three, four or maximum six FDM technique input factors for surface coarseness of thermoplastic material parts. PLA \& ABS are the generally used thermoplastic raw materials to make any $3 \mathrm{D}$ physical object using FDM technique [23]. Both these materials have more tendencies to wrap due to non-uniform cooling rate during fabrication process [24]. Hence, to enlarge the utilization of FDM technique and produce components with various parts attributes, it might be supportive to think different materials for goodwill of researchers as well as to manufacture functional parts. Therefore, in this work the carbon based nylon (PA-CF) composite material is considered. But involvement of number of conflicting factors in FDM, there is requirement to have better parameters arrangement for attaining minimum $S R$ value. Therefore, in the present study maximum nine input process parameters are taken into consideration to study their effect on $S R$, and to get better parameters value for improving the superiority of FDM technique in terms of $S R$. An effectual method to assess the elucidation of this sort of issue is to setup the correlation between execution measures and manage parameters value through apposite modeling/ optimization technique. As a result, in this study central composite design, ANN and genetic algorithm (GA) are put into practice mutually to establish interaction \& correlation between nine parameters (layer thickness $(L T)$, temperature $(T)$, print speed $(S)$, outer wall speed $(O W S)$, raster angle $(R A)$, orientation $(O r$.$) , outer wall$ line width $(O W L W)$, infill overlap $(I O)$, infill line width $(I L W)$ ). The evolutionary algorithm ANNGA has been used for optimization. To fabricate test pieces nylon based carbon fiber composite material filament is used.

\section{EXPERIMENTAL DETAILS}

Nylon carbon fiber (PA-CF) filament is used to make various test pieces using FDM printer. $\mathrm{PA}-\mathrm{CF}$ is environment friendly, nylon based, $20 \%$ carbon fiber having good print quality with high finish printing effect filament. During fabrication of test pieces, $1.75 \mathrm{~mm}$ diameter (PA-CF) filament is used.

\subsection{Machining Performance Evaluation}

In this study, the output response value considered for examination the surface excellence is average surface roughness $\left(R_{a}\right)$. The cubical shape fabricated test pieces are shown in Fig. 1 as per ASTM standard D695. By using CAD software 3D model of test piece is designed and then transformed to STL standard file. The STL generated file is then imported to slicer software and converted in to GCODE file for FDM machine. Now one part per experiment is fabricated by the use of FDM 3D printer machine. For measuring the value of $S R$, Mitutoyo Talysurf is used as shown in Fig. 1. At each face (four), the surface roughness is measured and average of all values is taken as desired output value. The surface roughness is taken to be the representative value respectively.

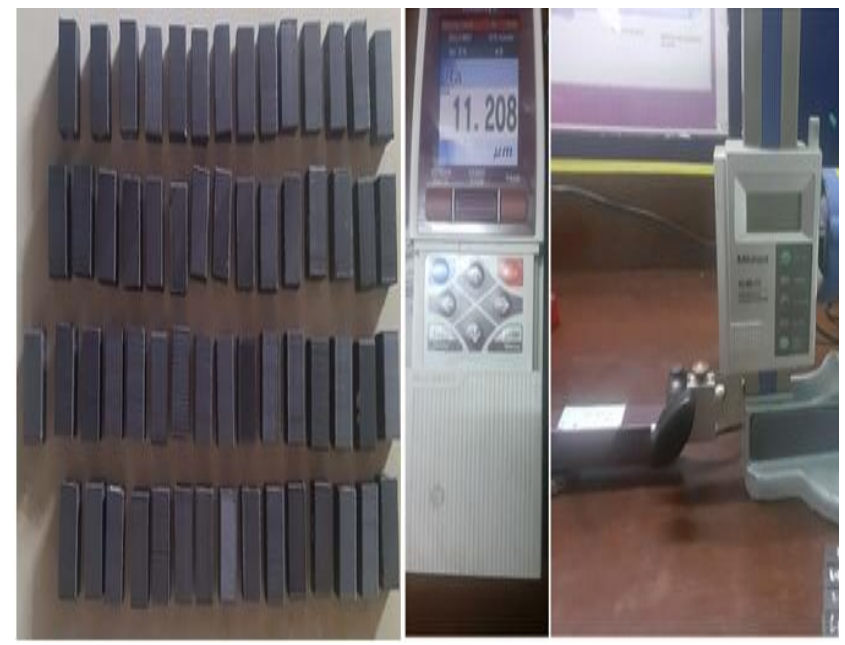

Fig. 1 - FDM fabricated test pieces and surface roughness measuring Mitutoyo Talysurf instrument

\subsection{Data Assortment}

In this work, the experiments design matrix is developed based on the face central composite design having value of alpha one (FCCD) procedure. The small factorial FCCD is designed with 61 different combination sets of the parameters having cubical points 55 , center points 5 , and star point 1 .

\subsection{Modeling and Development of ANN Model Using Experimental Data and Optimization Using GA}

In current years, the use of artificial intelligence is tremendously increasing for modeling and optimization of parameters in practically all pasture of engineering $[25,26]$. Precise control of process parameters to achieve 
better quality is a prerequisite condition. For obtained experimental value sets, using arithmetical techniques much more work has been conducted to develop fitting models. It is not easy to get any methodical model using basic process of physics. Therefore, ANN approach is used to model such complex problem process parameters. The model can be developed effectively based on the given information and trained very precisely for giving the better outcomes. The neural network derives its horizon from human brain or the human nervous system which is massively consists of large parallel interconnection of large number of neurons and that achieves the different perceptual, reorganization tasks etc. It is able to solve large computational problems efficiently. This technique has been successfully applied in different fields of engineering to solve linear and nonlinear problems with their modeling and optimization [27]. Its characteristics like acquiring, learning also make this technique to be used in future [28, 29].

The ANN model structure is generated for given multi-parameters mapping problem i.e. 9 input parameters and one response. The central composite design designed input/output data is imported as input and output data in the network. Tangent sigmoid activation function has been used for input layers and output layers. Gradient descent with bias learning and momentum weight has been used as adaptive learning function. The data for training, testing and validation have been taken as in the ratio of 0.7:0.15:0.15. Further, the proposed ANN model is trained and tested for learning and detaining the information using different algorithms. Finally, the best fitted ANN model is validated experimentally and then used with GA to optimize the input parameters.

GA is well known non-traditional optimization tool, generally applied to solve complex and multiparameters problems [30]. To optimize the parameters with ANNGA, the ANN model code is utilized as fitness function and integrated in to GA code [31].

\section{RESULTS AND DISCUSSION}

To optimize surface roughness of pieces manufactured by FDM, 61:4=244 measurements have been made on surface roughness tester in terms of average surface roughness $R_{a}$. On each piece, four measurements are taken and then average of all is considered as desired output value. The minimum surface roughness value obtained from $S R$ Mitutoyo Talysurf testing machine is $6.331 \mu \mathrm{m}$ corresponding to various optimum process parameters as $L T=0.15 \mathrm{~mm}, \quad T=230^{\circ} \mathrm{C}$, $S=40 \mathrm{~mm} / \mathrm{s}, \quad O W S=20 \mathrm{~mm} / \mathrm{s}, \quad R A=30^{\circ}$, $O W L W=0.35 \mathrm{~mm}$, Or. $=0^{\circ}, I O=100 \%, I L W=0.30 \mathrm{~mm}$.

The experimental test runs carried out were based on face central composite design (FCCD) matrix. The experimental design matrix has been utilized for the training, prediction and optimization via ANNGA. The evolutionary algorithm ANNGA, has been utilize to obtained optimal nine input parameters in specified range to achieve minimize the surface roughness.

\subsection{ANN Function Development \& Training}

The ANN has been trained with 61 sets of input process parameters $(L T, T, S, O W S, R A, O W L W, O r$, $I O, I L W)$ and an output response $(S R)$. The input matrix $[9 \times 61]$ and output $[1 \times 61]$ data set were feed for training, validation and testing. Different types training algorithms with learning functions (trains) like tainlm, trainbfg, traincgb etc. were used to perform training in MATLAB to achieve best regression value as shown in Table 1.

It is observed from table 1 that the higher value of regression has been achieved by using tainr function i.e. incremental algorithm with random order. The regression plot obtained using trainr function for training, validation, testing and overall have been shown in Fig. 2.
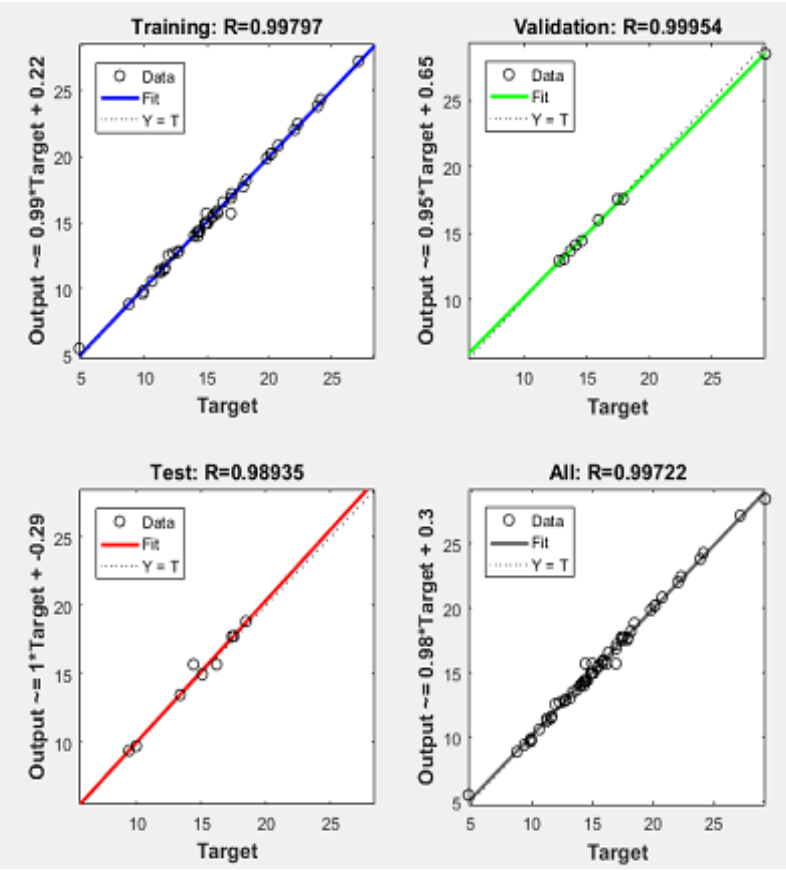

Fig. 2 - Regression plot for algorithm (trainr) incremental training with random order

\subsection{Surface Roughness Optimization by Configuring ANNGA Model}

The ANN combined with GA procedure has been developed to offer optimized parameters value to minimize the surface roughness. The GA with double vector

Table 1 - Regression values using different algorithms

\begin{tabular}{|c|c|c|c|c|c|c|c|c|}
\hline & Trainlm & Trainbfg & Traincgb & Traincgf & Traincgp & Trainrp & Traingoss & Trainr \\
\hline Training & 0.97489 & 0.7237 & 0.81802 & 0.67135 & 0.71537 & 0.93554 & 0.76275 & 0.99797 \\
\hline Validation & 0.32322 & 0.58663 & 0.95485 & 0.60644 & 0.61485 & 0.69206 & 0.62018 & 0.99954 \\
\hline Test & 0.61003 & 0.81852 & 0.68138 & 0.87842 & 0.95836 & 0.6973 & 0.878 & 0.98935 \\
\hline Overall & 0.85357 & 0.71031 & 0.89813 & 0.68937 & 0.7605 & 0.86321 & 0.73882 & 0.99722 \\
\hline
\end{tabular}


by specifying input parameters range and considering ANN modeling as fitness function has been iterated using crossover and mutation function. The population size has been taken as 200, stopping criteria has been considered as number of generations (350) and elite count is used as 1 , whereas the crossover fraction is taken as 0.9 and mutation rate is 0.05 . The crossover heuristic and mutation independent function have been used for producing off springs. The convergence of the surface roughness for obtaining input optimal parameters has been shown in Fig. 3. The minimum value of $S R$ obtained using ANNGA is $5.01788 \mu \mathrm{m}$, as shown in Fig. 3, corresponding to various optimum input factors as $L T=0.1776 \mathrm{~mm}, T=236.0609^{\circ} \mathrm{C}, S=40.7369 \mathrm{~mm} / \mathrm{s}$, $O W S=20.0676 \mathrm{~mm} / \mathrm{s}, R A=43.9177^{\circ}, O W L W=0.3445 \mathrm{~mm}$, Or. $=0.0018^{\circ}, I O=56.6295 \%, I L W=0.3488 \mathrm{~mm}$.

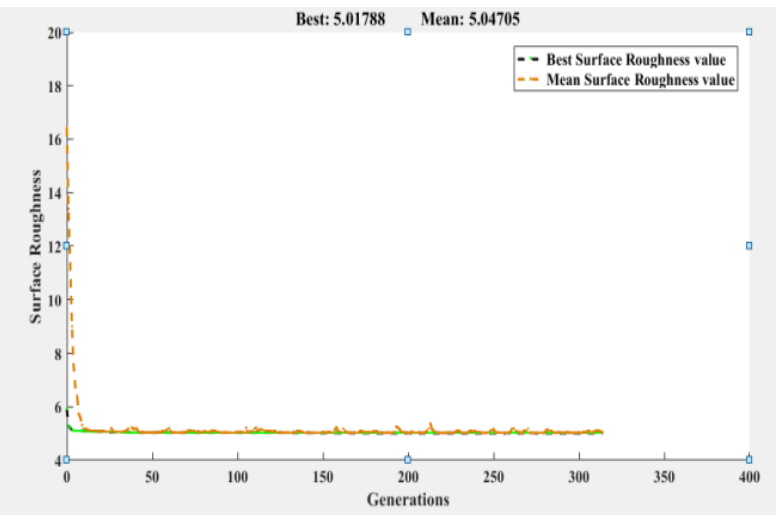

Fig. 3 - ANNGA convergence plot for $S R$ optimization

\subsection{ANNGA Developed Model Validation}

To validate the outcome obtained from GA integrated ANN model at the optimum input factors combination set as obtained in section 3.2, two test pieces are fabricated at optimal parameters using FDM machine. On each piece at four sides $S R$ value is taken and average of all is considered as desired output $S R$ value. Also one end-use part as shown in Fig. 4 is fabricated on the same optimum factors set as obtained in section 3.2. and measured the $S R$ value at various points. The average of $S R$ value measured on incilned and plain surface is cosidered as output $S R$ value. A comparison has been made between obtained ANNGA optimized results and experimental results as shown in Table 2. It is observed from the Table 2 that the results retreived from ANNGA and experimental results holds good in agreement.

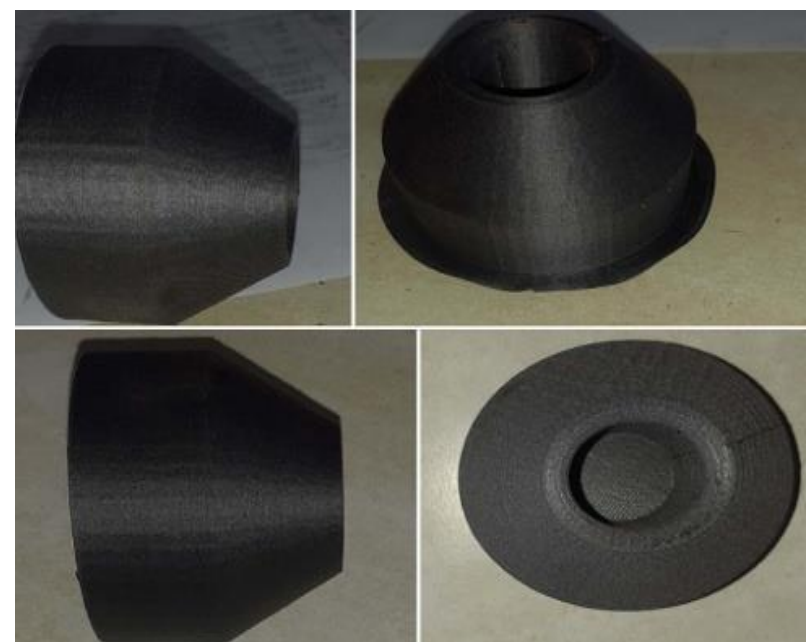

Fig. 4 - End-use part fabricated on FDM

\section{CONCLUSIONS}

In this work, FCCD, ANN and GA have been utilized to streamline the input factors for surface roughness of carbon based nylon composite material parts manufactured by FDM technique. The exploratory examination has been done by creating experimentation utilizing FCCD strategy. The nine FDM parameters are efficiently modeled with respect to $S R$. Surface quality, especially, surface unpleasantness is a significant trait of made items for designing application since it decides the usefulness of the part in a particular circumstance. In FDM technique, many input factors connect in a perplexing way impacting material testimony making it hard to create displaying and examination approaches for appraisal of resultant properties of fabricated parts. The ANN developed model was integrated with GA to get the optimum factors settings leading to the minimum surface roughness value $5.01788 \mu \mathrm{m}$ corresponding to various optimum input factors as $L T=0.1776 \mathrm{~mm}, \quad T=236.0609{ }^{\circ} \mathrm{C}, \quad S=40.7369 \mathrm{~mm} / \mathrm{s}$, $O W S=20.0676 \mathrm{~mm} / \mathrm{s}, R A=43.9177^{\circ}, O W L W=0.3445 \mathrm{~mm}$, $O r .=0.0018^{\circ}, I O=56.6295 \%, I L W=0.3488 \mathrm{~mm}$.

Therefore, the proposed ANNGA tool as a computational gadget utilized to help the planning assessment through choosing the optimum factors value for minimizing surface roughness of parts. The end-use fabricated part good surface finish shows great sign towards the ubiquity of FDM technique in each designing applications.

Table 2 - Comparison between ANNGA evolutionary algorithm results and experimental results

\begin{tabular}{|c|c|c|c|c|c|c|c|c|c|c|c|}
\hline S.no. & $L T$ & $T$ & $S$ & OWS & $R A$ & OWLW & Or. & $I O$ & $I L W$ & $\begin{array}{c}\text { ANNGA } \\
\text { results }\end{array}$ & $\begin{array}{c}\text { Experimental } \\
\text { results }\end{array}$ \\
\hline 1 & 0.1776 & 236.061 & 40.7369 & 20.067 & 43.9177 & 0.3445 & 0.0018 & 56.6295 & 0.3488 & 5.01788 & 5.1032 \\
\hline 2 & 0.1766 & 236.061 & 40.7369 & 20.067 & 43.9177 & 0.3445 & 0.0018 & 56.6295 & 0.3488 & 5.01788 & 5.2210 \\
\hline 3 & 0.1766 & 236.061 & 40.7369 & 20.067 & 43.9177 & 0.3445 & 0.0018 & 56.6295 & 0.3488 & 5.01788 & 5.0945 \\
\hline
\end{tabular}

\section{ACKNOWLEDGEMENTS}

DC acknowledges the Dr. Radha Krishana Founda- tion Fund, Maharshi Dayanand University Rohtak for Grant (vide no. DSW/2018/528). 


\section{REFERENCES}

1. O.A. Mohamed, S.H. Masood, J.L. Bhowmik, Mater. Lett. 193, 58 (2017).

2. S. Khodaygan, A.H. Golmohammadi, Int. J. Interact. Des. Manuf. 12, 1071 (2017).

3. F. Rayegani, G. Onwubolu, Int. J. Adv. Manuf. Technol. 73, 509 (2014).

4. U.K. uz Zaman, E. Boesch, A. Siadat, M. Rivette, A.A. Baqai, Int. J. Adv. Manuf. Technol. 101, 1215 (2019).

5. H. Chen, X. Yang, L. Chen, Y. Wang, Y. Sun, Sci. Rep. 6, 19207 (2016).

6. O.A. Mohamed, S.H. Masood, J.L. Bhowmik, Adv. Manuf. 3, 42 (2015).

7. A. Dey, N. Yodo, J. Manuf. Mater. Process. 3 No 3, 64 (2019).

8. V.B. Nidagundi, R. Keshavamurthy, C. Prakash, Mater. Today Proc. 2, 1691 (2015).

9. A.K. Sood, R.K. Ohdar, S.S. Mahapatra, J. Adv. Res. 3, 81 (2012).

10. T. Letcher, B. Rankouhi, S. Javadpour, Proceedings of the ASME 2015 International Mechanical Engineering Congress and Exposition (IMECE), 13 (Houston: TX: USA: 2015).

11. C.C. Wang, T.W. Lin, S.S. Hu, Rapid Prototyp. J. 13, 304 (2007).

12. B. Vasudevarao, D.P. Natarajan, M. Henderson, A. Razdan, Proceedings of the Solid Freeform Fabrication Proceedings, 251 (Austin: TX: USA: 2000).

13. R. Anitha, S. Arunachalam, P. Radhakrishnan, J. Mater. Process. Technol. 118, 385 (2001).

14. K. Thrimurthulu, P.M. Pandey, N.V. Reddy, Int. J. Mach. Tools Manuf. 44, 585 (2004).

15. D. Horvath, R. Noorani, M. Mendelson, Mater. Sci. Forum. 561-565, 2389 (2007)
16. X. Liu, M. Zhang, S. Li, L. Si, L, J. Peng, Y. Hu, Int. J. Adv. Manuf. Technol. 89, 2387 (2017).

17. A.K. Sood, R.K. Ohdar, S.S. Mahapatra, Mater. Des. 31, 287 (2010).

18. S.O. Akande, Int. J. Eng. Res. Technol. 4, 196 (2015).

19. A. Peng, X. Xiao, R. Yue, Int. J. Adv. Manuf. Technol. 73, 87 (2014).

20. T. Nancharaiah, D.R. Raju, V.R. Raju, Int. J. Emerg. Technol. 1 No 2, 106 (2010).

21. S. Assarzadeh, M. Ghoreishi, Int. J. Adv. Manuf. Technol. 39 , 488 (2008).

22. S.S. Agrawal, V. Yadava, Mater. Manuf. Process. 28, 381 (2013).

23. S. Deshwal, A. Kumar, D. Chhabra, CIRP J. Manufact. Sci. Technol. 31, 189 (2020).

24. D. Chhabra, S. Deswal, IOP Conference Series: Mater. Sci. Eng. 748 No 1,012007 (2020).

25. D. Yadav, D. Chhabra, R.K. Gupta, A. Phogat, A. Ahlawat. Mater Today: Proceedings 21, 1592 (2020).

26. D. Yadav, D. Chhabra, R.K. Garg, Mater. Today: Proceedings 21, 1583 (2020)

27. S. Ranganathan, T. Senthilvelan, G. Sriram, Mater. Manuf. Process. 25, 1131 (2010).

28. B.B. Pradhan, B. Bhattacharyya, Proc. Inst. Mech. Eng. Part B. J. Eng. Manuf. 223, 683 (2009).

29. P. Chokshi, R. Dashwood, D.J. Hughes, Comput. Struct. 190, 162 (2017).

30. K. Thrimurthulu, P.M. Pandey, N.V. Reddy, Int.J. Mach. Tools Manuf. 44 No 6, 585 (2004).

31. S. Deswal, R. Narang, D. Chhabra, Int. J. Interact. Des. Manuf. 13, 1197 (2019).

\title{
Оптимізація параметрів друку для поліпшення якості поверхні деталей, виготовлених 3 нейлонових композиційних матеріалів на основі вуглецю (PA-CF) з використанням еволюційного алгоритму
}

\author{
Sandeep ${ }^{1}$, Deepak Chhabra ${ }^{1}$, R.K. Gupta ${ }^{2}$
}

${ }^{1}$ Department of Mechanical Engineering, UIET, Maharshi Dayanand University, Rohtak Haryana India ${ }^{2}$ Department of Mechanical Engineering, Manipal University Jaipur, Jaipur, Rajasthan India

На поверхневі характеристики компонентів, виготовлених методами адитивного виробництва, сильно впливають вхідні параметри. У роботі важливі вхідні коефіціенти (товщина шару $(L T)$, темпера тура $(T)$, швидкість друку $(S)$, швидкість зовнішньої стінки $(O W S)$, кут растру $(R A)$, оріентація $(O r$.), ширина лінії зовнішньої стінки $(O W L W)$, заповнення перекриття $(I O)$, ширина лінії заповнення (ILW) принтера для моделювання методом наплавлення (FDM) змодельовані та оптимізовані для отримання кращої шорсткості поверхні $(S R)$ деталей, виготовлених з нейлонових композиційних матеріалів на основі вуглецю (РА-CF). Для розробки вхідної експериментальної матриці був використаний метод центрального композитного проектування, і на основі цих вхідних параметрів вимірювали шорсткість поверхні кожного прогону за допомогою приладу для вимірювання шорсткості поверхні Mitutoyo Talysurf. Було виготовлено загальну кількість зразків (61) з різними вхідними параметрами та випробувано їх шорсткості поверхні. Мінімальне значення шорсткості поверхні досліджуваних зразків експериментальною проектною матрицею складало 6,331 мкм. Моделювання та оптимізація експериментальної проектної матриці було проведено з використанням еволюційного алгоритму, тобто штучної нейронної мережі, інтегрованої з генетичним алгоритмом (ANNGA). Мінімальне значення, отримане з використанням ANNGA для шорсткості, становить 5,01788 мкм, що відповідає різним оптимальним вхідним коефіціентам, таким як $L T=0,1776$ мм, $\quad T=236,0609{ }^{\circ} \mathrm{C}, \quad S=40,7369 \mathrm{мм} / \mathrm{c}$, $O W S=20,0676 \mathrm{~mm} / \mathrm{c}, R A=43,9177^{\circ}, O W L W=0,3445 \mathrm{мm}, O r .=0,0018^{\circ}, I O=56,6295 \%, I L W=0,3488 \mathrm{мм}$. При цих оптимізованих значеннях вхідних коефіціентів також виготовляеться одна частина кінцевого використання та перевіряеться розроблена гібридна модель. ANNGA можна використовувати для передбачення, оптимізації факторів та результатів у будь-яких інженерних застосуваннях.

Ключові слова: Моделювання методом наплавлення; Штучна нейронна мережа, інтегрована з генетичним алгоритмом; Шорсткість поверхні; Експериментальна проектна матриця; Оптимізація. 